\title{
Brasilplast: Uma Visão da Indústria do Plástico
}

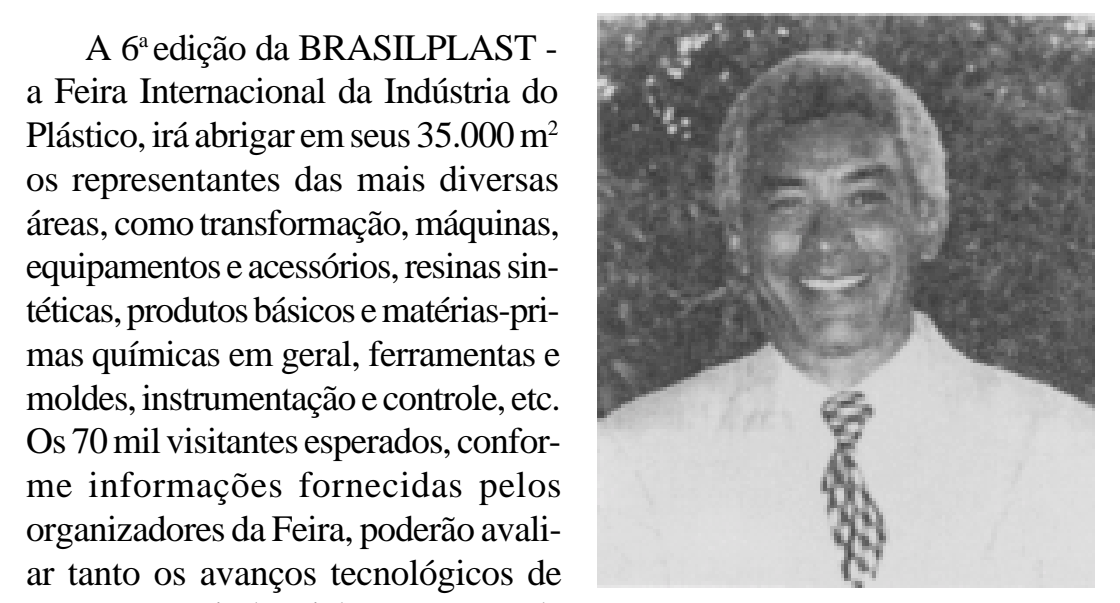

A $6^{\text {a }}$ edição da BRASILPLAST a Feira Internacional da Indústria do Plástico, irá abrigar em seus $35.000 \mathrm{~m}^{2}$ os representantes das mais diversas áreas, como transformação, máquinas, equipamentos e acessórios, resinas sintéticas, produtos básicos e matérias-primas químicas em geral, ferramentas e moldes, instrumentação e controle, etc. Os 70 mil visitantes esperados, conforme informações fornecidas pelos organizadores da Feira, poderão avalinosso parque industrial como o grau de competitividade do setor, representado por 450 expositores do Brasil e de outros 400 do exterior, dos quais $60 \%$ são da Alemanha, Estados Unidos e Itália.

A excelente performance dos transformadores de plásticos e dos fabricantes de resinas, que tiveram em 1995 um faturamento global de US\$ 8 bilhões, demonstra bem o potencial desse que é um dos maiores mercados não-saturados do mundo e explica o sucesso da Brasilplast. Consolidada internacionalmente por sua especialização e como elemento desencadeador de negócios, a Feira tornou-se o palco obrigatório por onde passam os lançamentos da indústria brasileira e também do exterior, cuja participação vem crescendo a cada evento.

É patente que a concorrência entre as empresas se torna mais acentuada na época da realização da Feira, todavia seus resultados têm sido altamente positivos, na medida em que esse espaço aberto para a divulgação das novas tecnologias serve também como fator de incentivo para a atualização de nosso parque industrial. $\mathrm{O}$ conhecimento do que "os outros" estão fazendo leva ao conhecimento de nossas deficiências e ao desejo de mudanças, de aprimoramento. Não há como não enxergar o que existe no mercado. A saída, então, é fazer como os outros: investir em Recursos Humanos e investir em Tecnologia para poder acompanhar o mercado e, quem sabe, liderar um dia.

A ABPol, por ter entre seus principais objetivos a formação e a atualização dos profissionais atuando em polímeros, estará realizando seu $4^{\circ}$ CONGRESSO BRASILEIRO DE POLÍMEROS, em Salvador, de 28 de setembro a 2 de outubro próximo. Da mesma forma que a indústria, estaremos reunindo a comunidade brasileira de polímeros para a troca de experiências e de conhecimento nos mais diversos temas. A participação de pesquisadores de renome internacional traz para o Congresso a "concorrência" do conhecimento de fora e do qual não podemos nos furtar e que, no final, acaba por motivar nosso próprio desenvolvimento.

A indústria do plástico mais uma vez está de parabéns pela realização da Brasilplast. Não estamos mais em uma "torre de marfim". Estamos abertos para nós mesmos e para o mundo, o que nos deixa mais aptos a buscar novos instrumentos de modernização. A ABPol tem sentido os reflexos dessa mudança com a crescente participação da indústria nos congressos realizados, antes vistos como eventos puramente acadêmicos e hoje como uma fonte de troca de experiências e conhecimento.

Fica aqui o convite para a participação recíproca de profissionais da indústria e do meio acadêmico, tanto na Brasilplast como no $4^{\circ} \mathrm{CBPol}$, porque, a bem da verdade, todos querem - e devem - saber o que está acontecendo tanto na Feira como no Congresso. 